\title{
A detailed petrophysical evaluation in turbiditic stages of the Caruaçu Member - Maracangalha Formation, Recôncavo Basin.
}

\author{
Candido da Silva, T.; Ramos, M.M.; Dutra, R.; Santos, F.V.; Santos, R.B.; Lupinacci, W.M.; Freire, A.F.M. \\ Universidade Federal Fluminense (UFF)
}

Copyright 2021, SBGf - Sociedade Brasileira de Geofísica.

This paper was prepared for presentation during the $17^{\text {th }}$ International Congress of the Brazilian Geophysical Society held in Rio de Janeiro, Brazil, $16-19$ August 2021.

Contents of this paper were reviewed by the Technical Committee of the $17^{\text {th }}$ International Congress of the Brazilian Geophysical Society and do not necessarily represent any position of the SBGf, its officers or members. Electronic reproduction or storage of any part of this paper for commercial purposes without the written consent of the Brazilian Geophysical Society is prohibited.

\begin{abstract}
During the Neocomian evolution of the Recôncavo Basin Rifte, lacustrine sandstones of the Maracangalha Formation were formed through the occurrence of debris flows (Pitanga Mb.) and turbidity currents (Caruaçu Mb.). In this study, we evaluate the Caruaçu Mb. in the Massapê oil/gas field, which is characterized by having lenticular layers of fine to medium sandstones, appling a high-resolution integration of rock and well logs data. We recognized 23 turbiditic stages in this member from a characteristic gamma ray (GR) upward decrease, typical for turbidites. The main goal of this work is to characterize and individualize these 23 turbiditic stages aiming to estimate and evaluate their petrophysical properties, such as clay volume (Vclay), effective porosity (PHIE), water saturation (Sw), and net pay (effective hydrocarbon thickness) to provide maps of hPhiSo (height $x$ effective porosite $x$ oil saturation) to understand the spatial distribution of these respective properties for each turbiditic stage. Our high-resolution workflow helps the increasing of the recovery factor of the Massapê Field, promoting the characterization of low permeability turbiditic sandstones. This study was carried out through the evaluation of open hole well logs of 32 wells, and the maps of the spatial distribution of hPhiSo. We used GR (gamma ray), CAL (caliper), NPHI (neutrons), RHOB (density), and RT (resistivity) curves that provided the basis for the interpretation of lithology, and as input for the calculation of petrophysical properties, calibrated with rock data, gently assigned by ANP and Petrobras. To estimate Vclay, the Larionov's method was used because it provides an intermediate scenario when compared to the Linear and Stieber methods. For PHIE calculation, the Gaymard \& Poupon method was chosen because it is adequate to characterize gas or light oil zones. Sw was calculated applying the Simandoux equation, considering the influence of clays. We calculated the net pay considering cutoff values for the Vclay $<15 \%, \mathrm{PHIE}>9 \%$ ), and $\mathrm{Sw}<50 \%$, and we created maps of Vclay and hPhiSo using the kriging method for interpolation. Therefore, this work is expected to enhance the knowledge of the turbiditic reservoirs of the Massapê Field, giving higher robustness and optimizing exploratory and development processes in the Recôncavo Basin or similar turbiditic reservoirs.
\end{abstract}

Keywords: Turbidites; Petrophysics; Caruaçu Member; Maracangalha Formation; Massapê Field; Recôncavo Basin. 